UDK 336.64: 67

JEL Classification M 21, M 41, G 3

DOI 10.31375/2226-1915-2019-4-119-130

M.V. Matviienko

Ph.D., associate Professor of the «Entrepreneurship and Tourism Department» marinimus029@gmail.com

ORCID 0000-0002-5753-683X

Odessa National Maritime University, Odessa, Ukraine

\title{
THE FINANCIAL ASPECT OF REVENUE MANAGEMENT AT THE HOSPITALITY BUSINESS
}

\begin{abstract}
The article analyzes the process, approaches and methods of revenue management in the hospitality business, changes in management and the prospects of using new approaches in revenue management in the hotel business. It is noted that the industry has a high level of services individualization, which complicates the process of data collection and processing, as well as the complexity of building an effective pricing policy. The role of pricing policy in the process of revenue management is determined, the main elements and levers of influence are defined, and the range of ethical problems in pricing for hotel services related to price discrimination is outlined. The role of enterprise income in this field as a major factor is substantiated, which influences the further possibilities of functioning and development and other indicators of efficiency. The role of revenue management policy in determining the efficiency of the activity and the possibility of its further functioning are shown. For the hospitality business to function effectively, it is important to create a revenue management system that maximizes them in the short, medium and long term, without losing customers and reputation, and tightly cont-rols timeliness and revenue. The following stages of revenue management have been noted and management decisions and consequences system identified: analysis of pre-vious periods data, taking into account past mistakes and peculiarities of the environment; development of pricing policies, taking into account segmentation and pricing discrimination; marketing decisions affecting financial and operating performance; finding ways to increase revenue; budgeting and the possibility of operational change; control over revenues; adjustment and revenue impact; comparing the values obtained with the target values. The analysis concludes that an effective revenue management system using IT technologies allows solving complex multifactor problems and to make timely decisions of managerial, organizational and financial character that directly or indirectly affect the efficiency of the hospitality business.
\end{abstract}

Keywords: income, revenue management, finance, enterprise, methods of revenue adjustment.

(C) Матвиенко М.В., 2019 
УДК 336.64: 67

JEL Classification M 21, M 41, G 3

DOI 10.31375/2226-1915-2019-4-119-130

Матвіснко М.В. к.е.н., доцент кафедри «Підприємництво і туризм» marinimus029@gmail.com ORCID0000-0002-5753-683X

Одеський наиіональний морський університет, Одеса, Украӥна

\section{ФІНАНСОВИЙ АСПЕКТ УПРАВЛІННЯ ДОХОДАМИ В СФЕРІ ГОСТИННОСТІ}

Анотація. У статті подано аналіз підходів та методів управління доходами в бізнесі в сфері гостинності, змін у галузі фiнансового управління та перспектив використання нових підходів в управлінні надходженнями в готельному бізнесі. Визначена роль політики иіноутворення та окреслене коло етичних проблем у ціноутворенні на готельні послуги. Обтрунтована роль доходів підприємств у иій галузі як найважливішого чинника, щзо впливає на подальші можливості функціонування та розвитку, та на інші показники ефективності. Показана роль політики управління доходами у визначенні результативності діяльності та можливості подальшого функиіонування. Для ефективного функиіонування підприємства у сфері гостинності важливо створити таку систему управління доходами, яка дозволить їх максимізувати в коротко-, середньо- та довгостроковій перспективі без втрат клієнтів та репутаиіï, а також організувати суворий контроль за своєчасністю та обсягом доходу. Визначені етапи управління доходами: аналіз доходів попередніх періодів; пошук шляхів збільшення доходу; складання бюджету; контроль над доходами; регулювання та коригування доходу; порівняння отриманих значень із ијльвовими показниками. Аналіз дозволяе зробити висновок, щзо методи управління доходами дозволяють своєчасно приймати рішення управлінського, організаційного та фінансового характеру, шо прямо чи опосередковано впливають на ефективність діяльності підприємства в галузі гостинності.

Ключові слова: дохід, управління доходами, фінанси, підприємство, методи коригування доходів.
УДК 336.64: 67

JEL Classification M 21, M 41, G 3

DOI 10.31375/2226-1915-2019-4-119-130

Матвиенко М.В.

к.э.н., доцент кафедры

«Предпринимательство и туризм» marinimus029@gmail.com

ORCID0000-0002-5753-683X

Одесский национальный морской университет, Одесса, Украина

\section{ФИНАНСОВЫЙ АСПЕКТ \\ УПРАВЛЕНИЯ ДОХОДАМИ В СФЕРЕ ГОСТЕПРИИМСТВА}

Аннотация. В статье приведен анализ подходов и методов управления доходами в гостиничном бизнесе, изменения в этой сфере и перспективы использования новых подходов в управлении в гостиничном бизнесе. Обосновывается роль дохода предприятия в этой сфере как важнейтего фактора, влияющзего на дальнейшее функиионирование $и$ возможности развития и другие показатели деятельности. Показана роль политики уnравления доходами в определении эффективности деятельности и возможности дальнейшего функиионирования. Для эффективного функииоонирования предприятия в сфере гостеприимства важно создать такую систему управления доходами, которая позволит их максимизировать в коротком, среднем и долгосрочном периоде, а также организовать строгий контроль над своевременностью и объемом доходов. Обоснованы этапы управления доходами, в том числе: анализ доходов предыдущих периодов; поиск путей увеличения доходов; бюджетирование; контроль доходов; урегулирование и корректировки уровня доходов; сравнение полученных значений с иелевыми показателями. Проведенный анализ позволяет сделать выводы о том, что методы управления доходами позволяют своевременно принимать решения управленческого, организаиионного и финансового характера, прямо или косвенно влияюшие на эффективность деятельности предприятия в сфере гостеприимства.

Ключевые слова: доходы, управление доходами, финансы, предприятие, методы корректировки доходов. 
Problem statement. The revenue is a prerequisite for almost all businesses, because it is a source of the development, the revenue is the basis for calculating profits, financing current expenses, and tax compliance. The revenue indicates demand for products and / or services. The revenue is the basis for self-financing of an activity, but provided that its size is sufficient to cover costs and liabilities, as well as to gene-rate net income. Therefore, increasing the company's revenue contributes to improving its financial position.

The high competition, diversification of enterprises, high segmentation and rapid development of the hospitality industry lead to the urgent need for costeffective and efficient enterprise revenue management and tight control over the adherence to customer-friendly pricing policies. In such circumstances, the search for new methods and approaches to managing income and their financial justification becomes a paramount need.

The hospitality businesses in Ukraine are often faced with an insufficient level of pricing due to a number of the internal and external problems. The internal ones are often associated with small sizes and, as a consequence, the low management cost, excessive orientation on existing prices in the market without the coordination with their own characteristics, external ones are mostly related to the underdevelopment of the hospitality sector in Ukraine. Thus, the pricing policy often turns into profit management as a last resort. This approach through yield management leads to negative consequences, such as lower prices for the most places, hotel rooms and other services without the economically justifying such actions. This, in turn, leads to a decrease in the profitability. That is, businesses offer much higher discounts during off-peak periods, and the low price rising for the peak periods that they cannot always afford financially. It leads to a decrease in the level of total revenue.

Review of the last research and publications. Revenue management, also known as yield management, is an essential instrument for matching supply and demand by dividing customers into different segments based on their purchase intentions and allocating capacity to the different segments in a way that maximizes a particular firm's revenues (El Haddad, Roper \& Jones, 2008).

Kimes (1989) and Kimes \& Wirtz (2003) define revenue management as the use of information systems and pricing strategies to provide the right service to the right customer at the right price at the right time. It places revenue management practices in the field of marketing management, where it plays a key role in demand generation (Cross, Higbie \& Cross, 2009) and consumer behavior management (Anderson $\&$ Xie, 2010). Income management theory is of great benefit not only for marketing research but also more tangible for operational management (e.g. Talluri \& van Ryzin, 2005) and pricing research (Shy, 2008).

It can also be noted that most income surveys are characterized by incompleteness, that is, they highlight individual elements inherent in this category. Sometimes the approaches of different economists to the nature of income are contradictory [2, p. 203].

Modern scholars such as M.S. Pushkar, F.F. Butynets, V.S. Suharsky, I.M. Boychuk and others interpret the 
term revenue differently. Some compare it to the costs of production plus profit, or income from sales, or cash inflows or other income, cash or tangible assets, while others understand it like economic benefits or increase assets that increase equity $[2 ; 6]$.

Tasks of research. The purpose of the article is to recognize the notion of revenue management, the stages and methods of revenue management in a hospitality industry, as well as to outline the limitations, including moral ones, of using different management practices.

The basic material of research.

Based on the research of scientific literature, it can be concluded that the hospitality enterprise revenue is an economic benefits, both in monetary and property terms, from its main or non-core activities, which leads to an increase in the assets or a decrease in the liabilities of the enterprise. Since revenue is an indicator of efficiency and determines the ability of the enterprise to continue the operation, it requires the establishment of an effective revenue management policy.

Revenue management of the enterprise is the part of financial management, that includes financial policies, methods, tools and decisions. Those enterprises that have a high level of organization and management are more successful than their competitors. That is, large networked hotels are often more manageable and they can control their income easier, despite their revenue complexity and dynamism, than smaller hotels and hostels. And, with laudable pricing policies, large hotels can earn revenue during the dead of season. Therefore, building a revenue management mechanism as part of a common management system is a difficult but necessary task for business executives.

First of all, it should be noted that the revenue management system must comply with such principles as: completeness of reflection, reliability, self-sufficiency, interest of owners in increasing revenue, comparability, ensuring financial stability, timeliness.

It is also necessary to identify the main factors on which the revenue management system depends:

- Pricing policy and price system;

- Volume of service;

- Operating expenses and additional expenses;

- Marketing policy (fig. 1).

The term «revenue management» is used in many enterprises to define the income management process, different methods that are suitable for allocating scarce resources, such as hotel rooms for different segments of demand (eg, business travelers or vacationers) (Ingold et al. Eds 2000). Revenue management is based on two strategic levers:

- The capacity management (availability and duration control);

- The demand-based pricing

(Kimes \& Chase 1998).

Revenue management is the application of disciplined analytics that predict consumer behavior at the micromarket levels and optimize product availability and price to maximize revenue growth. The primary aim of revenue management is selling the right product to the right customer at the right time for the right price and with the right pack. The essence of this discipline is in understanding customers' perception of product value and accurately aligning product prices, placement and availability with each customer segment [1]. 


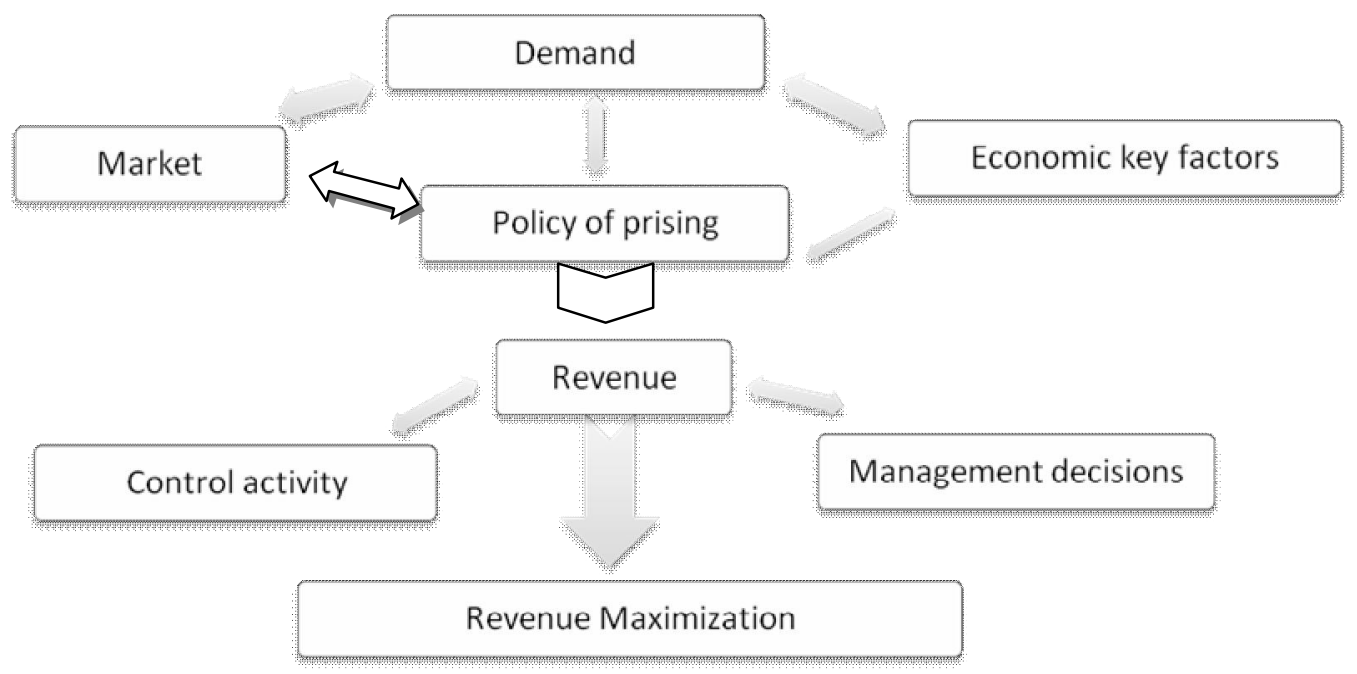

Fig. 1. Main Factors of Revenue Management System

\section{Source: Own elaboration}

Thereby, the decision making process in revenue management for hospitality sector can be depicted on Fig. 2.

Hospitality businesses face with important decisions about what services to provide, when to provide them, to whom, and at what cost. Revenue management uses data-driven tactics and strategies to solve the task of increasing revenue. The revenue management process combines data getting and operations research with strategy, understanding customer behavior, and partnerships with the sales force. Today, a finance manager should be analytics and detail oriented, able to think strategically and manage the sales relationship. Thus, with regard to the financial part, we obtain the following structure of the process of managing revenues (e.g. hotel industry) (fig. 3).

Implementing such a complex and multilevel process requires the ade- quate technical support that not only captures the facts of service delivery at the specific prices, but also allows developing scenarios and forecasts. It is clear that the cost of such systems does not allow them to be used in small businesses, that is, we can speak about the underutilization of sophisticated revenue management systems among hoteliers worldwide. Complex revenue management products are typically owned by large network hotels (e.g., Marriott (One Yield), IHG (Concerto), Choice Hotels (ChoiceEdge), and Best Western (Best Rev)).

Other hotels and hospitality businesses use different tools from Excel spreadsheets to heuristics (fig. 4). This does not mean that the results they produce are not important, but such systems cannot do millions of calculations to, for example, add up to the best price per room. 


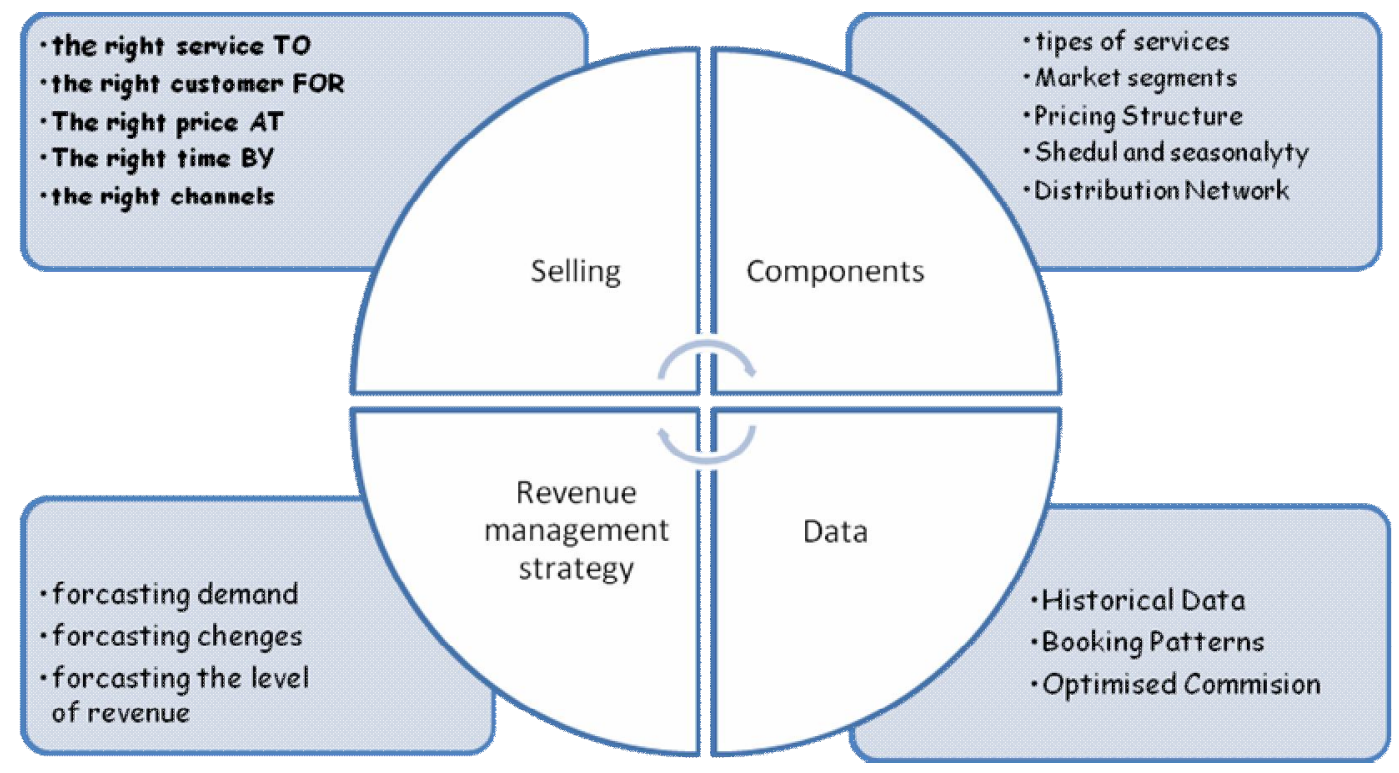

Fig. 2. The decision making process in revenue management for hospitality sector

\section{Source: Own elaboration}

The disadvantage of complex revenue management systems is that there are usually difficulties with scaling and copying, as well as the need to hire professionals capable of working in them.

Thus, the emergence of new or small players does not necessarily select customers from known players, but instead focuses on the main market of small and independent hotels, which have the know-how to apply distribution and revenue strategies.

The penetration the revenue management systems into management of small hospitality businesses is still low. According to Hotel Tech Report, only 7 percent of the world's hotel business uses software to manage revenue and make pricing decisions. An Expedia
Group survey shows that permeability is less than 3 percent (July 2017). The total figure quoted in the industry is anywhere from 10 to 20 percent, given that some of the largest hotel chains have their own technology.

The penetration the revenue management systems into management of small hospitality businesses is still low. According to Hotel Tech Report, only 7 percent of the world's hotel business uses software to manage revenue and make pricing decisions.

An Expedia Group survey shows that permeability is less than 3 percent (July 2017). The total figure quoted in the industry is any-where from 10 to 20 percent, given that some of the largest hotel chains have their own technology. 
DEVELOPMENT OF MANAGEMENT

AND ENTREPRENEURSHIP METHODS

ON TRANSPORT, № 4 (69), 2019
РОЗВИТОК МЕТОДІВ

УПРАВЛІННЯ ТА ГОСПОДАРЮВАННЯ

НА ТРАНСПОРТІ, № 4 (69), 2019

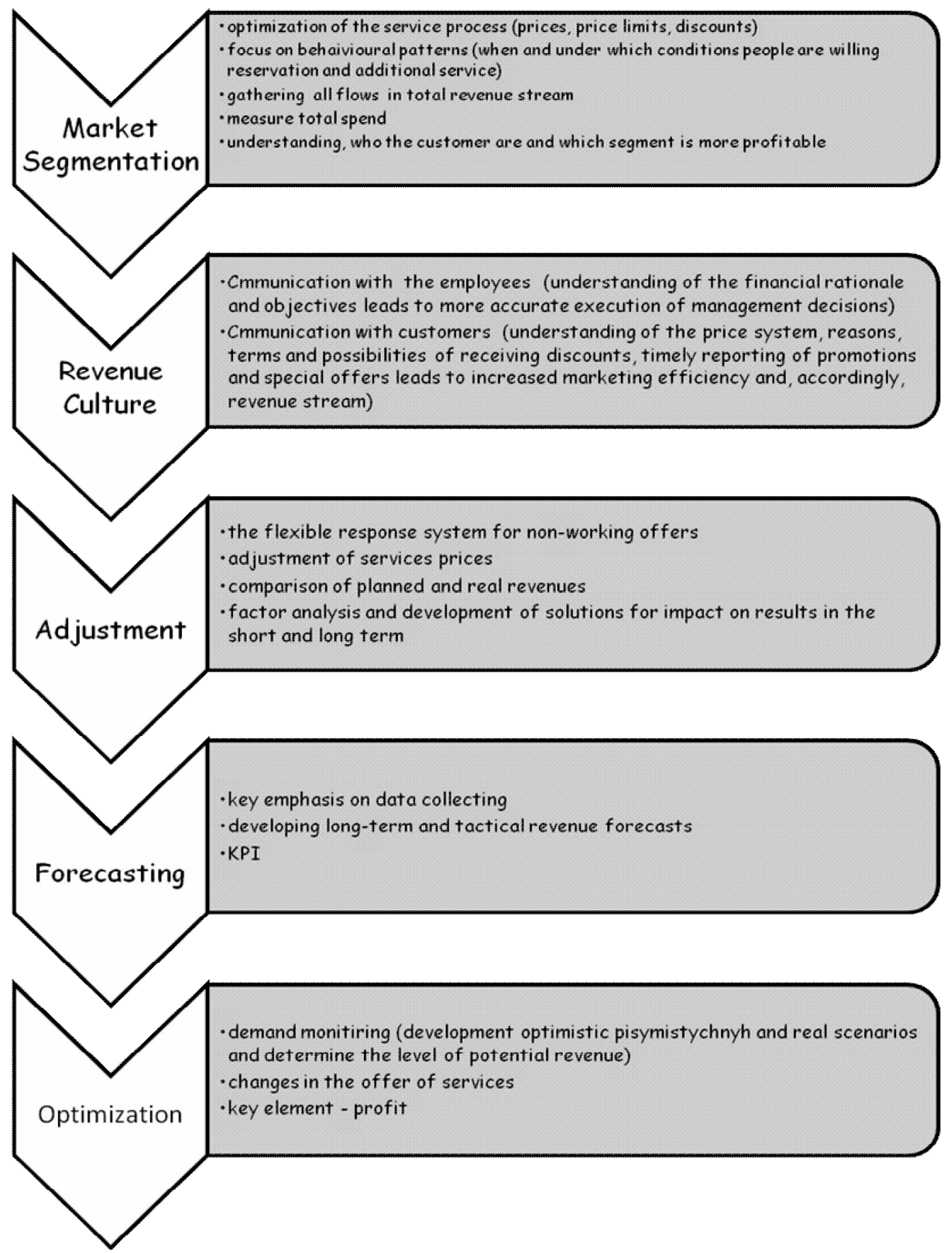

Fig. 3. Requirement for revenue management process (financial aspect)

Source: Own elaboration 


\section{Hotels}

\section{In-house $\square$ Third party RMS $\quad$ No RM Tech}

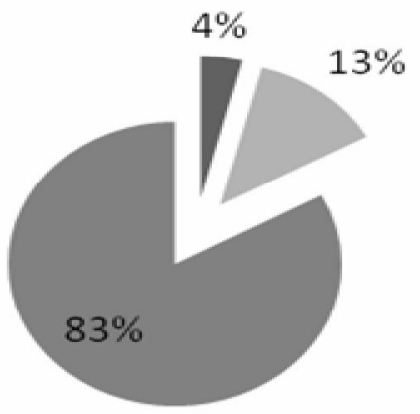

Fig. 4. Revenue Management Tech Penetration

\section{Source: adapted from Skift Research, as of April 2019}

The main revenue management tool is pricing, which, through price diversification for different customer segments, acts as both a sales regulator and a revenue generator (fig. 5).

Revenue management applies to any business that has a relatively fixed perishable inventory capacity, manages demand (that is, through booking), has high fixed and low variable costs, and provides varying degrees of customer sensitivity to prices (Wirtz \& Kimes 2007).

In recent years, a number of studies have been conducted on the impact of price discrimination on customer relationships, with the specific purpose of exploring how customers perceive revenue management tools and the potential conflicts that may result from their use. There are also several empirical as well as a number of theoretical studies that have identified factors that significantly affect fair price perceptions. Such factors are: the similarity of transactions and the choice of other comparative parties, the distribution of costs and profits and the signs of inequality, the buyer-seller relationship, the social norms and the knowledge of the market (Xia, Monroe \& Cox 2004). In order to apply price discrimination, demand is broken down into several different price segments according to the client's sensitivity to prices. Hotel companies, offering multiple prices for virtually the same service, can increase revenue and reduce consumer surplus. However, since customers are accustomed to comparing prices with prices paid by other customers, as well as with the rates they have paid in the past, it is imperative that the motivation behind the different price levels is transparent.

While profit management involves more cost management, revenue management encompasses a wide range of revenue opportunities. As noted, a hospitality business can use a variety of levers to control its level and revenue structure: 


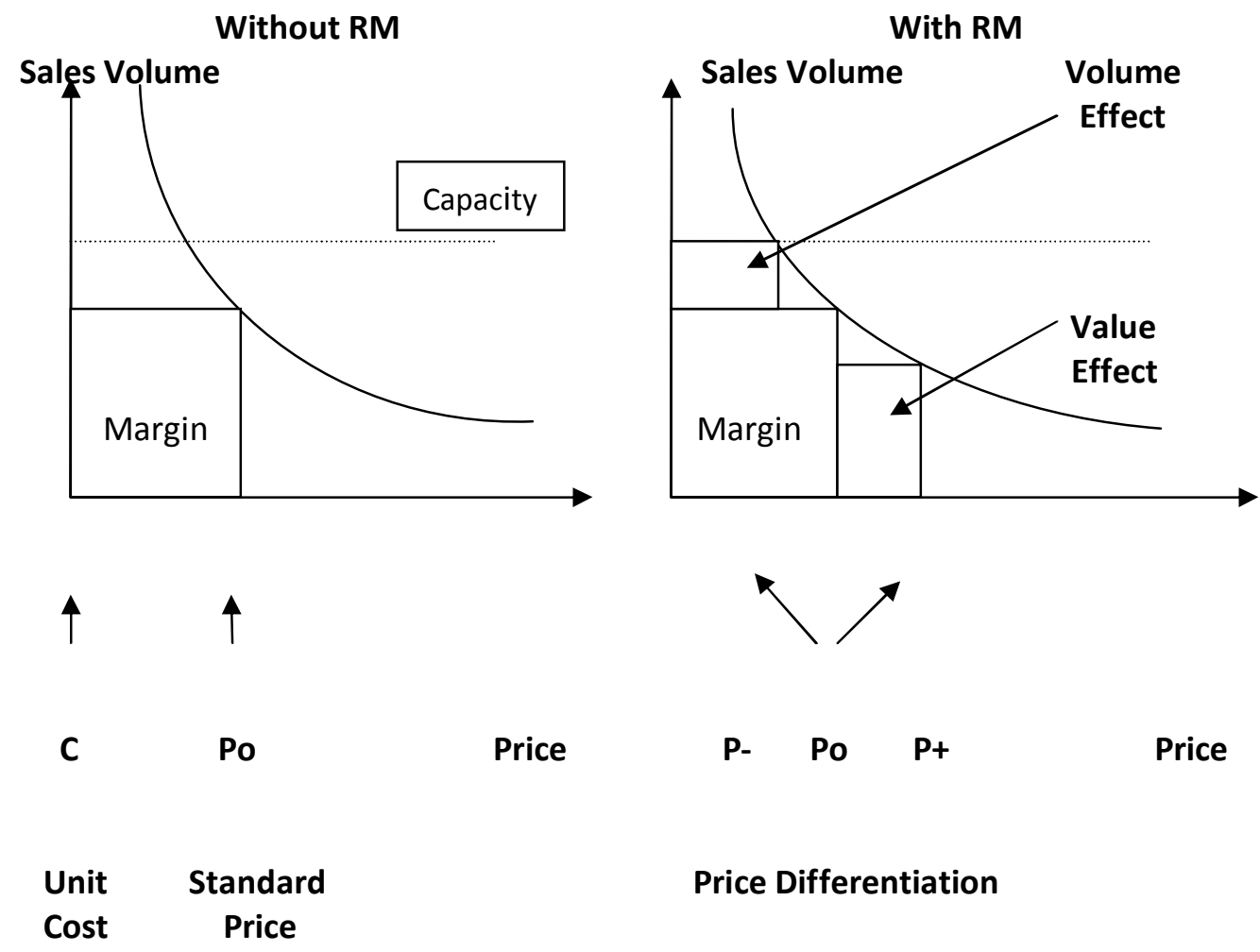

Fig. 5. Technology of Hotel Revenue Management

Source: adapted from Wouter Greets, Skift Research, 2019

- Pricing. Pricing strategy and pricing tactics. The main goal is to predict cost and set specific prices to capture that value for different segments. Pricing strategy dictates what an enterprise should do, pricing tactics determine what methods are used. Tactics involves creating pricing tools.

- Marketing. Price promotions allow companies to sell larger volumes of services, diversifying their prices. Revenue management techniques allow determining the customer response to the stocks to strike a balance between the volume growth and the profitability. An effective tool helps maximize revenue.

- Channels. Manage the revenue through different distribution channels. Channels are the system of relation with customers with different price sensitivities. For example, customers who book online are usually more price sensitive than customers who make 
reserva-tions by phone or in person. Different channels often have the different costs and margins associated with these channels. By using multiple channels, revenue management techniques can calculate appropriate levels of discounts through opaque channels to promote more services without losing the quality of public perception.

- Data collection. The hospitality enterprise revenue management process begins with data collection. The system must collect and store historical customer service data and behavior. Any data that reflects the details of the services offered, their prices, competition and customer behavior should be analyzed.

- Segmentation. Once relevant data is collected, market segmentation is a key factor in market pricing and revenue maximization. Success depends on the ability to segment customers into similar groups based on the calculation of customer price responses to specific products, based on time and place. Revenue management seeks to determine the value of a product in a very narrow micro-market at a specific point in time, and then chart customer behavior at the border to determine the maximum revenue from those micromarkets [1]. Market segmentation based on customer behavior is the most important factor for the next step forecasting demand related to clustered segments.

- Prognostication. Revenue management requires forecasting various elements such as demand, inventory availability, market share and the overall market. Forecasting is an essential revenue management task and takes a lot of time to develop, maintain and implement; see Financial forecast. Quantitybased forecasts that use time series models, reservation curves, cancellation curves, etc., project future demand volumes, such as reservations or purchased products.

- Optimization. Optimization involves evaluating several options for how and to whom to sell your services. Optimization involves solving two important problems in order to maximize revenue. The first is to determine which objective function to optimize. The business makes the decision by balancing price optimization, total sales, contribution margins, or even customer value. Second, the business must decide which optimization technique to use.

- Dynamic re-evaluation. Revenue management requires a firm to constantly re-evaluate its prices, products and processes to maximize profits. In a dynamic market, an effective revenue management system continually re-evaluates the variables involved to move dynamically with the market.

In recent years, fairly sophisticated mathematical models have been developed, such as dynamic programming introduced by Talluri and Van Riesen [14], which will allow us to more accurately determine the effective level and price system. Price bargaining is the determination of the minimum price that a seller must take for a lower level and is a popular control mechanism for hotel and car rental businesses. Models derived from developments in financial engineering are interesting but unstable and difficult to put into practice. Profit management tends to focus on environments that are less sustainable than financial markets.

Optimization can help an enterprise adjust prices and allocate capacity among market segments to maximize 
expected revenue. This can be done at different levels of detail:

- Services (for example, booking different rooms, additional services);

- by group of services (all premium numbers, all single numbers);

- by market (hotel services, catering, supplies, sightseeing);

- in general (all types of services provided by the company);

Conclusions. Revenue management is highly effective for the hospitality industry, as it has the multistream of revenue from different types of services and the individualized service (each product is different in terms of time, space or structural characteristics). Businesses which use revenue management have an effective cash flow management system and the ability to support management decisions. Predicting demand and flexibility in pricing for hotel services, supplies, sightseeing, and desires in advance, buyers will perform their own sorting based on price sensitivity, demand sensitivity or time of purchase.
Thus, the main purpose of revenue management is to provide the optimum combination of services at different price levels at different times or for different segments of customers. The system tries to maintain a distribution of services over time, which makes the flow of revenue balanced and high.

Effective revenue management maximizes (or at least substantially increases) revenue generation for the same number of service units, guided by high demand / low demand forecasts, effectively shifting demand from high demand periods to low demand periods and charging a premium for late booking. Although revenue management systems tend to generate more revenue, revenue streams tend to arrive later in the booking horizon as there is more opportunity to delay sales at premium prices. This approach makes it possible, through the introduction of a much larger number of price points, to respond to the diversity of interests and purchasing drivers of its customers.

\section{REFERENCES}

1. Cross, R. (1997). Revenue Management: Hard-Core Tactics for Market Domination. New York, NY: Broadway Books.

2. Talluri, K., and van Ryzin, G. (1999) Revenue Management: Research Overview and Prospects. Transportation Science 33:233-256.

3. Chase, Nicole. 2007. Revenue management redefined. Hotels, February 1, 2007.

4. Cross, R., Higbie, J. \& Cross, Z. (2010). Milestones in the Application of Analytical Pricing and Revenue Management. Journal of Revenue and Pricing Management

5. Cross, R., Higbie, J. \& Cross, D. (2009). Revenue management's renaissance: a rebirth of the art and science of profitable revenue generation. Cornell Hospitality Quarterly 50: 56-81.

6. Mauri, A.G. (2013). Hotel Revenue Management: Principles and Practices, Pearson.

7. Blodgett, J.G., Wakefield, K.L. \& Barnes, J.H. (1995). The effects of customer service on consumer complaining behavior. Journal of Services Marketing (9)4, 31 42.

8. Bolton, L.E., Warlop, L. \& Alba, J.W. (2003). Consumer perceptions of price (un)fairness. Journal of Consumer Research (29)4, 474-491. 
9. Campbell, M.C. (1999). Perceptions of price unfairness: Antecedents and consequences. Journal of Marketing Research (36).

10. Choi, S. \& Mattila, A.S. (2004). Hotel revenue management and its impact on customers' perceptions of fairness. Journal of Revenue \& Pricing Management (2)4, 303-314.

11. Choi, S. \& Mattila, A.S. (2005). Impact of information on customer fairness perceptions of hotel revenue management. Cornell Hotel and Restaurant Administration Quarterly (46)4, 444-451.

12. Choi, S. \& Mattila, A.S. (2006). The role of disclosure in variable hotel pricing. Cornell Hotel and Restaurant Administration Quarterly (47)1, 27-35.

13. Ingold, A., McMahon-Beattie, U. \& Yeoman, I. (eds.) (2000). Yield Management: Strategies for the Service Industries. London: Continuum. Kahneman, D., Knetsch, J.L. \& Thaler, R. (1986). Fairness and the assumptions of economics. Journal of Business (59)4, 285-300.

14. Kimes, S.E. \& Chase, R.B. (1998). The strategic levers of yield management. Journal of Service Research (1)2, 156-166.

15. Kimes, S.E. \& Wirtz, J. (2003). Has revenue management become acceptable? Journal of Service Research (6)2, 125-135.

16. Konow, J. (2003). Which is the fairest one of all?: A positive analysis of justice theories. Journal of Economic Literature (41)4, 1188-1239.

Article received 21.11.2019

Reference a JournalArtic: Matviienko, M. (2019). The financial aspect of revenue management at the hospitality business. Development of management and entrepreneurship methods on transport. 4, 119-130. DOI 10.31375/2226-1915-2019-4119-130.

Стаття надійшла до редакиії 21.11.2019

Посилання на статтю: Matviienko, M. (2019). The financial aspect of revenue management at the hospitality business // Розвиток методів управління та господарювання на транспорті: Зб. наук. праць, 2019. №4 (69). С. 119-130. DOI 10.31375/2226-1915-2019-4-119-130. 